\title{
Parasites of Zoonotic Interest Detected in Felis catus domesticus in Midwestern Brazil
}

\author{
Parasitos de Interesse Zoonótico Detectados em Felis catus domesticus no Centro-Oeste do \\ Brasil
}

\author{
Stephanie Ballatore Holland Lins; ; Maria Elizabeth Cavalheiros Dorval ${ }^{\mathrm{a}}$; Elenir Rose Jardim Cury Pontes ${ }^{\mathrm{a}}$; Ana Paula \\ Antunes Nogueirac; Eduardo de Castro Ferreira*b; Maria de Fatima Cepa Matos ${ }^{\mathrm{a}}$
}

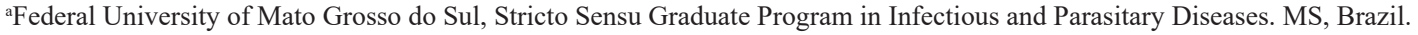

${ }^{b}$ Universidade Anhanguera-Uniderp, Stricto Sensu Graduate Program in Environment and Regional Development. MS, Brazil. ${ }^{c}$ Control Center of Zoonoses, City Hall of Campo Grande. MS, Brazil.

*E-mail: eduardodecastroferreira@gmail.com
\end{abstract}

\begin{abstract}
Interactions between humans and animals can be considerably beneficial to human well-being, and the demand for domestic cats as pets has increased in recent years. Despite these benefits, however, cats may contribute to environmental dissemination of zoonotic pathogens, with potential risks to human health. The purpose of this study was to investigate the prevalence and diversity of feline parasites of zoonotic interest in Campo Grande, the capital city of Mato Grosso do Sul state, Midwestern Brazil, where studies on feline parasitic fauna remain scarce. Fecal samples from 210 male and female cats of varying ages, sheltered at the local Center for Zoonosis Control, were examined. Spontaneous and ether centrifugal sedimentation were used to detect the parasites, found in 149 animals $(71.0 \%), 93$ (62.4\%) of which were infected with a single parasitic species and $56(37.6 \%)$ with two or more species. Ten parasitic species were detected, where Ancylostoma sp. was the most frequent (65.2\%), followed by Platynosomum concinnum (21.0\%), Cystoisospora sp. (7.1\%), Aelurostrongylus abstrusus (1.9\%), Strongyloides sp. (1.9\%), Dipylidium caninum (1.4\%), Giardia sp. (1.0\%), Toxocara sp. (1.0\%), Physaloptera praeputialis (1.0\%), and Sarcocystis sp. $(0.5 \%)$. The results obtained are relevant to human and veterinary public health policies and demonstrate the cats' role in the transmission chain of parasitic zoonoses, particularly in urban areas. The findings can also serve to raise awareness among veterinarians and cat owners on the importance of preventive interventions to ensure healthier cohabitation with pets by reducing human exposure to cat borne parasites in urban areas.
\end{abstract}

Keywords: Zoonoses. Felines. Helminths. Protozoa. One Health.

\section{Resumo}

As interações entre humanos e animais podem ser consideravelmente benéficas para o bem-estar humano, e a demanda por gatos domésticos como animais de estimação aumentou nos últimos anos. Apesar desses beneficios, no entanto, os gatos podem contribuir para a disseminação ambiental de patógenos zoonóticos, com riscos potenciais para a saúde humana. O objetivo deste estudo foi investigar a prevalência e diversidade de parasitos de interesse zoonótico em felinos de Campo Grande, capital do estado de Mato Grosso do Sul, no Centro-Oeste do Brasil, onde estudos sobre a fauna parasitária felina permanecem escassos. Foram examinadas amostras fecais de 210 gatos machos e fêmeas de idades variadas, abrigados no Centro de Controle de Zoonoses local. Sedimentação espontânea e sedimentação por centrifugação em éter foram utilizadas para detectar os parasitos, encontrados em 149 animais (71,0\%), 93 (62,4\%) dos quais foram infectados com uma única espécie parasitária e 56 (37,6\%) com duas ou mais espécies. Foram detectadas dez espécies parasitárias, sendo Ancylostoma sp. o mais frequente (65,2\%), seguido por Platynosomum concinnum (21,0\%), Cystoisospora sp. (7,1\%), Aelurostrongylus abstrusus (1,9\%), Strongyloides sp. (1,9\%), Dipylidium caninum (1,4\%), Giardia sp. (1,0\%), Toxocara sp. (1,0\%), Physaloptera praeputialis (1,0\%) e Sarcocystis $s p .(0,5 \%)$. Os resultados obtidos são relevantes para as políticas de saúde pública humana e veterinária e demonstram o papel dos gatos na cadeia de transmissão das zoonoses parasitárias, principalmente nas áreas urbanas. As descobertas também podem servir para conscientizar os veterinários e donos de gatos da importância de intervenções preventivas para garantir uma coabitação mais saudável com animais de estimação, reduzindo a exposição humana a parasitos transmitidos por gatos em áreas urbanas.

Palavras-chave: Zoonoses. Felinos. Helmintos. Protozoários. Saúde Única.

\section{Introduction}

The interaction between living beings (men, animals and pathogens) that share the same environment, must be considered as a unique and dynamic system, where the functioning of each component is closely interconnected and dependent on the other (CALISTRI et al., 2013).

Emerging and re-emerging infections are currently acknowledged as a global challenge (TAYLOR et al., 2001; GUIMARÃES et al., 2010), and 61\% of the human pathogens worldwide have been categorized as zoonotic (WHO, 2009).

The concern for zoonoses is compounded by human contact with pets being made more ubiquitous by growing urban sprawl into previously unpopulated areas and by the frequent presence of pets in public spaces and public transportation, as well as their transit across national borders, increasing the likelihood of environmental contamination and, consequently, of pathogen transmission, with potentially fatal outcomes (CHOMEL; SUN, 2011).

Zoonotic events control in urban areas is currently 
centered on dogs, while overlooking the widespread presence of pet cats is a situation that calls for a reevaluation of the zoonotic potential of this species in terms of public health (GENARO, 2010).

In Brazil, data on parasitism in felines are scarce (BEUGNET et al., 2013) but the pet cats population has been estimated at 22.1 million nationally, or 1.9 per household on average. In Midwestern Brazil, cats are found in 14.3\% of households (IBGE, 2015). The purpose of this study was to estimate the prevalence and diversity of parasites with zoonotic potential in domestic cats (Felis catus domesticus) in Campo Grande county, Mato Grosso do Sul state, Midwestern Brazil.

\section{Material and Methods}

The study was based on fecal samples collected between September 2014 and May 2015 from 210 male and female cats of varying ages sheltered at Campo Grande Center for Zoonosis Control. The Center shelters lost and stray animals for an established period, after which those not reclaimed by their owners are euthanized. Only cats scheduled for euthanasia were used in this study. The project was authorized by the Ethics Committee on the Use of Animals (CEUA / UFMS) under protocol No. 609/2014.

The animals were grouped by sex and age. Adult cats were defined as those aged six months or older. When absent from the records, age was estimated from dentition.

Geographical animals' origin took into account the county's stratification into six health districts (North, South, East, West, Central, and Rural) adopted by the Center for Zoonosis Control, which, for the present purposes, were regrouped as rural region (comprising farms and rural settlements), central region (corresponding to the Central health district), and suburban region (combining the North, South, East, and West districts).

Fecal samples from euthanized animals were collected from the rectal ampulla and stored in universal specimen flasks containing $10 \%$ of formalin for subsequent parasitological examination at the Clinical Parasitology Laboratory of the Biological and Health Sciences Center at the Federal University of Mato Grosso do Sul (UFMS). Parasite detection was performed by spontaneous sedimentation (HOFFMAN et al., 1934) and ether centrifugal sedimentation (BLAGG et al., 1955), which allow protozoan cysts and oocysts, as well as helminth eggs and larvae, to be observed.

Data on the prevalence of detected parasites are reported together with their respective $95 \%$ confidence intervals $(95 \%$ CI). To compare proportions between the variable "parasite" and other variables (sex, age, animal origin, and domicile status), the Chi-squared test or Fisher's exact test were applied using Epi Info 7.1.1.14 software (Centers for Disease Control and Prevention, Atlanta, GA, USA).

\section{Results and Discussion}

Of the 210 animals examined, 149 (71.0\%; 64.8-77.1\%, $95 \% \mathrm{CI})$ were infected and $61(29.0 \%)$ tested negative. Of these 149 animals, $93(62.4 \%)$ were infected with a single parasite species and $56(37.6 \%)$ with two or more species. The association between Ancylostoma sp. and Platynosomum concinnum (13.3\%) was the most frequent, followed by Ancylostoma sp. and Cystoisospora sp. (4.7\% each).

Table 1 shows the prevalence rates of the diagnosed parasitic species. Infection by Ancylostoma helminths was the most frequent, at $65.2 \%$ (137/210), followed by Platynosomum concinnum, at $21.0 \%(44 / 210)$.

Table 1 - Cats (Felis catus domesticus) diagnosed with protozoan and helminth infection. Campo Grande, Mato Grosso do Sul, $2015(n=210)$

\begin{tabular}{|l|c|c|r|}
\hline \multicolumn{1}{|c|}{ Parasite* } & N & \% & \multicolumn{1}{c|}{ 95\% CI } \\
\hline Ancylostoma sp. & 137 & 65.2 & $58.8-71.7$ \\
\hline Platynosomum concinnum & 44 & 21.0 & $15.4-26.5$ \\
\hline Cystoisospora sp. & 15 & 7.1 & $3.7-10.6$ \\
\hline Aelurostrongylus abstrusus & 4 & 1.9 & $1.3-2.5$ \\
\hline Strongyloides sp. & 4 & 1.9 & $1.3-2.5$ \\
\hline Dipylidium caninum & 3 & 1.4 & $0.9-1.9$ \\
\hline Giardia sp. & 2 & 1.0 & $0.5-1.4$ \\
\hline Toxocara sp. & 2 & 1.0 & $0.5-1.4$ \\
\hline Physaloptera praeputialis & 2 & 1.0 & $0.5-1.4$ \\
\hline Sarcocystis sp. & 1 & 0.5 & $0.2-0.8$ \\
\hline
\end{tabular}

*Infection by likely multiple parasite types.

Source: Research data.

The high prevalence of parasitosis found in the present study was within the $31.5-100 \%$ range reported for different Brazilian regions (COELHO et al., 2009; COLOGNESI et al., 2018; DALL'AGNOL et al., 2010; FERRAZ et al., 2019; FUNADA et al., 2007; MÓSENA et al., 2019; PIVOTO et al., 2013; ; RAMOS et al., 2020; SERRA et al., 2003).

The high prevalence of hookworms has considerable epidemiological relevance, not only for the impact on feline health, but also for the high risk of environmental contamination. Larval forms, particularly of A. braziliense, may cause cutaneous larva migrans syndrome, also known as serpiginous dermatitis (popularly referred to as "bichogeográfico" in Brazil), of cosmopolitan distribution and higher frequency in tropical and subtropical regions (LIMA, 2005). In the county investigated, temperatures in the $25-30{ }^{\circ} \mathrm{C}$ range, typical of tropical climates, are common, encouraging the development and environmental persistence of parasites. No differences in the prevalence of $A$. braziliense in humans have been reported regarding host age, sex, or ethnicity, but its zoonotic potential is greater among children, often more vulnerable for their likelihood of playing on potentially contaminated substrates, such as sandy beaches or sand boxes in public parks (BRICARELLO et al., 2018; ROCHA et al., 2019; SANTARÉM et al., 2004) or located in school yards (ARAÚJO et al., 2000).

In Brazil, infection rates for the trematode Platynosomum 
concinnum range from $1.07 \%$ to $40 \%$, depending on the region investigated and the animals' domicile status (GENNARI et al., 1999; RAGOZO et al., 2002; MUNDIM et al., 2004). The prevalence observed in the present study was very similar to the $26.03 \%$ rate found by another author (RAMOS et al., 2013), possibly owing to similarities in climate, subjects, and collection sites. Furthermore, the cats' behavior and predatory instinct may explain the prevalence observed in the present investigation, although higher rates have been reported for free-ranging animals (SALOMÃO et al., 2005).

Despite the serious risks posed to cats, platynosomiasis has not been reported as a zoonosis. Its epidemiology and pathogenesis, however, have not been fully elucidated, requiring further investigation on epidemiological features (occurrence and distribution). Importantly, infection by Platynosomum concinnum should be included in differential diagnosis of liver disease (RAMOS et al., 2013).

Only two animals were infected by Toxocara sp. (1\%), similarly to the rate observed in another study (FERREIRA et al., 2013), but in sharp contrast with prevalence rates detected in other Brazilian regions, in the $16.58-43.1 \%$ range (COELHO et al., 2009; GENNARI et al., 1999; PIVOTO et al., 2013; RAGOZO et al., 2002; RAMOS et al., 2020).

Despite the low prevalence of Giardia sp. in the samples, ingestion of as few as 10-100 cysts can prove sufficient for symptomatic infection in humans (RENDTORFF, 1954). In Brazil, the prevalence of Giardia sp. in animals ranges from 5.0 to 38.1\% (BRINKER et al., 2009; COELHO et al., 2009; DALL'AGNOL et al., 2010; FERREIRA et al., 2013; FERRAZ et al., 2019; FUNADA et al., 2007; MORAES et al., 2019; MÓSENA et al., 2019), but rates are known to depend on geography and detection method, as well as on the animals' age, habits, and clinical condition (BALLWEBER et al., 2010).

The prevalence of Cystoisospora sp., of only 7.1\% $(15 / 210)$, was in sharp contrast with rates found for the states of São Paulo (RAGOZO et al., 2002), Rio de Janeiro (SERRA et al., 2003), Paraná (FERREIRA et al., 2013), and Mato Grosso (GAVIOLI et al., 2011), of 26.09-70.6\%. In a recent study carried out in Rio de Janeiro with domiciled cats $(\mathrm{n}=57)$ and shelter cats $(\mathrm{n}=336)$, the prevalence of Cystoisospora sp. was $8.33 \%$ and $26.20 \%$ respectively (RAMOS et al., 2020).

The presence of a single case of sarcocystosis corroborates the low prevalence of Sarcocystis sp. reported in other studies (SERRA et al., 2003; RAGOZO et al., 2002).

Infection with Physaloptera praeputialis, of only $1 \%$ in the present investigation, has been reported in the 1.0654.54\% range elsewhere in Brazil (GENNARI et al., 1999; SILVA et al., 2001; MUNDIM et al., 2004; ISHIZAKI et al., 2006; FERREIRA et al., 2013), although higher prevalence rates can be detected with active search of adult parasites on animal necropsy (SILVA et al., 2001; ISHIZAKI et al., 2006). Although rarely diagnosed in humans, the zoonotic potential of $P$. praeputialis should not be overlooked. Difficulties in identifying eggs of this parasite (highly similar to decorticated eggs of Ascaris), both in human and veterinary samples, can lead to underestimation of prevalence rates (CLEELAND et al., 2013).

With a prevalence rate of $1.9 \%$ (4/210), Aelurostrongylus abstrusus is being reported for the first time in Campo Grande, but prevalence rates from $2 \%$ to $29.5 \%$ have been reported elsewhere (CAMPOS et al., 1974; MUNDIM et al., 2004; EHLERS et al., 2013; RAMOS et al., 2013).

Factors such as global warming and changes in the vectors population dynamics, combined with frequent animals' transit, may play a key role in the growing number of reports of A. abstrusus infection (TRAVERSA; GUGLIELMINI, 2008). Given its wide geographic range, this type of infection has recently been shown to be much more common than previously thought (RASSOULI et al., 2015).

A prevalence rate of $1.9 \%$ was observed for Strongyloides sp., similar to that of $1.6 \%$ detected by Gennari (GENNARI et al., 1999), and in contrast to the $25 \%$ observed in a study with domiciled cats in Rio de Janeiro (RAMOS et al., 2020). Strongyloidiasis accounts for $60-85 \%$ mortality among immunocompromised patients. Affecting roughly 100 million globally, the disease mostly occurs in institutional settings, rural areas, and populations of lower socioeconomic status (IRIEMENAM et al., 2010).

Possibly, the actual infection prevalence by helminths released as larvae in the environment is higher than the rates found in the present study, which did not employ the Baermann method ideal for diagnosing larval forms.

Dipylidium caninum had a low prevalence, corroborating other reports (DALL'AGNOL et al., 2010; GARCÍA-AGUDO et al., 2014), and in contrast to the $16.67 \%$ observed in a study with domiciled cats in Rio de Janeiro (RAMOS et al., 2020). In humans, the risk of infection is low in adults, but high among young children, as this latter group is more exposed to accidental ingestion of fleas or contact with saliva of pet mammals. Non-specific clinical manifestations can render infection asymptomatic, under-recognized, or under-reported (NARASIMHAN et al., 2013), masking the true incidence of D. caninum.

No statistical difference was observed in parasite prevalence rates $(p>0.05)$ relative to host sex. Infection was detected in $71.9 \%(92 / 128)$ of females and $69.5 \%(57 / 82)$ of males. No differences were detected in the distribution of parasitized animals by county region or between household pet and stray animals. This fact is in agreement with other investigations (COELHO et al., 2009; RAMOS et al., 2013; GAVIOLI et al., 2011).

Despite showing no differences in parasitism status, stray cats have increased risk of exposure to parasitic infection, owing to predation of small rodents, birds, and arthropods, as well as exposure to contaminated drinking water and food scavenged from garbage containers (RAGOZO et al., 2002; TORRICO et al., 2008). However, the growing interest 
in adoption of homeless cats has increased the number of domiciled and semi-domiciled animals, with possible undesirable implications for human health (COELHO et al., 2009).

In the present study, a combination of centrifugation and spontaneous sedimentation allowed detection of different parasite species, although the methods employed may exhibit low sensitivity, depending on species-specific features (GENNARI et al., 1999; BLAZIUS et al., 2005; TAPARÓ et al., 2006; MANDARINO-PEREIRA et al., 2010).

The recognition that human health is directly associated with animal and environmental health is a fundamental element in monitoring and controlling threats to public health, and this is called One Health. For this reason, it is necessary to foster knowledge about how diseases spread among people, animals and the environment (CDC, 2013).

Among the many benefits of a One Health approach, there is a greater possibility of preventing and fighting parasitic diseases, but in order for One Health to occur effectively, knowledge about this new approach and its importance for the population must be stimulated. Health managers should be aware of the importance of the professionals participation from different areas in the decision-making process and in the area of basic health (CIRNE; CABRERA, 2019). Such works, in a way, indicate that doctors, veterinarians, other health professionals, researchers and even governmental and nongovernmental bodies, must work together to ensure the health preservation in its most diverse forms (DAY, 2010).

\section{Conclusion}

The parasites detected in the present investigation are relevant to both human and veterinary public health policies, calling for interventions to reduce human exposure to these agents in urban areas.

Knowledge on the epidemiology of major zoonoses in felines is imperative for veterinarians, enabling these professionals to not only deliver timely treatment to affected animals, but also to provide owners with guidance on exposure risks.

\section{References}

ARAÚJO, F.R. et al. A. Larva migrans cutânea em crianças de uma escola em área do Centro-Oeste do Brasil. Rev. Saúde Pública, v.34, n.1, p.84-85, 2000. doi: 10.1590/S003489102000000100015

BALLWEBER, L.R. et al. Giardiasis in dogs and cats: update on epidemiology and public health significance. Trends Parasitol., v.26, n.4, p.180-189, 2010. doi: 10.1016/j.pt.2010.02.005

BEUGNET, F. et al., Ocorrência de parasitos gastrointestinais e fatores de risco de parasitismo em gatos domésticos urbanos de Santa Maria, RS, Brasil. Ciênc. Rural, v.43, n.8, p. 1453-1458, 2013. doi: $10.1590 / \mathrm{S} 0103-84782013000800018$

BLAGG, W. et al., A new concentration technic for the demonstration of protozoa and helminth egg in faeces. Am. J. Trop. Med. Hygiene, v.4, n.1, p.23-28, 1955. doi: 10.4269/ ajtmh.1955.4.23
BLAZIUS, R.D. et al. Ocorrência de cães errantes soropositivos para Leptospira spp. na Cidade de Itapema, Santa Catarina, Brasil. Cad. Saúde Pública, v.21, n.6, p.1952-1956, 2005. doi: 10.1590/S0102-311X2005000600046

BRICARELLO, P.A. et al. Contamination by parasites of zoonotic importance in fecal samples from Florianopolis Beaches, Santa Catarina State, Brazil. Braz. J. Vet. Res. Animal Sci., v.55, n.1, p.1-10, 2018. doi: 10.11606/issn.1678-4456.bjvras.2018.133259

BRINKER, J.C.; TEIXEIRA, M.C.; ARAÚJO, F.A.P. Ocorrência de Giardia sp. em cães e gatos no município de Caxias do Sul, RS. Rev. FZVA, v.16, n.1, p.113-119, 2009.

CALISTRI, P. et al. The components of 'one world - one health' approach. Transboundary Emerg. Dis., v.60, n.2, p.4-13, 2013. doi: $10.1111 /$ tbed.12145

CAMPOS, D.M.B.; GARIBALDI, I.M.; CARNEIRO, J.R. Prevalência de helmintos em gatos (Felis catus domesticus) de Goiânia. Rev. Patol. Trop., v.3, n.4, p.355-359, 1974. doi: $10.1590 / \mathrm{S} 0037-86822003000300003$

CDC - Centers for Disease Control and Prevention, National Center for Emerging and Zoonotic Infectious Diseases (NCEZID). One Health Basics, 2018. Available in: <https://www.cdc.gov/ onehealth/basics/index.html > Accessed on: 14 may 2020.

CHOMEL, B.B.; SUN, B. Zoonoses in the bedroom. Emerg. Infectious Dis., v.17, n.2, p.167-172, 2011. doi: 10.3201/ eid1702.101070

CIRNE, F.S.L.; CABRERA, J.G.P. Ações em saúde única para redução de parasitoses infantis: revisão integrativa de literatura. Saber Digital, v.12, n.2, p.136-149, 2019.

CLEELAND, L.M. et al. Clarifying prehistoric parasitism from a complementary morphological and molecular approach. J. Arch. Scie, v.40, n.7, p.3060-3066, 2013. doi: 10.1016/j. jas.2013.03.010

COELHO, W.M.D. et al. Ocorrência de parasitos gastrintestinais em amostras fecais de felinos no município de Andradina. Rev. Bras. Parasitol. Vet., v.18, n.2, p.46-49, 2009. doi: 10.4322/ rbpv.01802010

COLOGNESI, M.C. et al. Avaliação coproparasitológica de gatos errantes da Represa Municipal de São José do Rio Preto / SP. COMFEL 2018 - Congresso Medvep Internacional de Medicina Felina p. 21-23, 2018.

DALL'AGNOL, L.P. et al. Parasitos gastrintestinais em gatos naturalmente infectados no município de Santa Maria no estado do Rio Grande do Sul, Brasil. Acta Vet. Bras., v.4, n.3, p.181-184, 2010. doi: 10.21708/avb.2010.4.3.1781

DAY, M. J. One Health: the small animal dimension. Vet. Record, v.167, n.22, p.847-849, 2010. doi: 10.1136/vr.c6492

EHLERS, A.; MATTOS, M.J.T.; MARQUES, S.M.T. Prevalência de Aelurostrongylus abstrusus (Nematoda, Strongylida) em gatos de Porto Alegre, Rio Grande do Sul. Rev. FZVA, v.19, n. 1, p. 97-104, 2013.

FERRAZ, A. et al. Frequência de parasitos gastrintestinais, presentes em fezes de cães e gatos, analisadas no laboratório de doenças parasitárias da UFPel, durante o ano de 2017. Scie. Anim. Health, v.7, n.1, p. 41-53, 2019. doi: 10.15210/sah.v7i1.14786

FERREIRA, F.P. et al. Frequência de parasitas gastrointestinais em cães e gatos do município de Londrina, PR, com enfoque em saúde pública. Semina Ciênc. Agrárias, v.34, n.6, p.3851-3858, 2013. doi: 10.5433/1679-0359.2013v34n6Sup12p3851

FUNADA, M.R. et al. Frequência de parasitos gastrintestinais em cães e gatos atendidos em hospital-escola veterinário da cidade de São Paulo. Arq. Bras. Med. Vet. Zootecnia, v.59, n.5, p.1338- 
1340, 2007. doi: 10.1590/S0102-09352007000500038

GARCÍA-AGUDO, L.; GARCÍA-MARTOS, P.; RODRÍGUEZIGLESIAS, M. Dipylidium caninum infection in an infant: a rare case report and literature review. Asian Pacific J. Trop. Biomedicine, v. 4, n. 2, p. 565-567, 2014. doi: 10.12980/ APJTB.4.2014APJTB-2014-0034

GAVIOLI, F.A. et al. Ocorrência de endoparasitos em gatos de Cuiabá, Mato Grosso, Brasil. Arch. Vet. Scie., v. 16, n. 3, p. 25-30, 2011. doi: 10.5380/avs.v16i3.19498

GENARO, G. Gato doméstico: futuro desafio para controle da raiva em áreas urbanas? Pesq. Vet. Bras., v.30, n.2, p.186-189, 2010. doi: 10.1590/S0100-736X2010000200015

GENNARI, S.M. et al. Ocorrência de protozoários e helmintos em amostras de fezes de cães e gatos da cidade de São Paulo. Braz. J. Vet. Res. Animal Sci., v.36, n.2, p.87-91, 1999. doi: 10.1590/S1413-95961999000200006

GUIMARÃES, F.F. et al. Ações da vigilância epidemiológica e sanitária nos programas de controle de zoonoses. Vet. Zootec., v.17, n.2, p. 151-162, 2010.

HOFFMAN, W.A.; PONS J.A.; JANER, J.L. The sedimentation concentration method in Schistosomiasis mansoni. J. Public Health, v.9, p.283-291, 1934.

IBGE - Instituto Brasileiro de Geografia e Estatística. Pesquisa nacional de saúde: 2013: acesso e utilização dos serviços de saúde, acidentes e violências: Brasil, grandes regiões e unidades da federação. IBGE, Coordenação de Trabalho e Rendimento, 2015.

IRIEMENAM, N.C. et al. Strongyloides stercoralis and the immune response. Parasitol. Int., v.59, n.1, p.9-14, 2010. doi: 10.1016/j.parint.2009.10.009

ISHIZAKI, M.N. et al. Frequência e intensidade parasitária de helmintos gastrintestinais de felinos da zona urbana do município de Araçatuba, SP. ARS Vet., v.22, n.3, p.212-216, 2006.

LIMA, W.S. Larva migrans. In: NEVES, D.P. Parasitologia humana. São Paulo: Atheneu, 2016. p.309-312,

MANDARINO-PEREIRA, A. et al. Prevalence of parasites in soil and dog feces according to diagnostic tests. Vet. Parasitol., v.170, n.1-2, p.176-181, 2010. doi: 10.1016/j.vetpar.2010.02.007

MORAES, L.F.et al. Estudo retrospectivo e comparativo da prevalência de Giardia sp. em cães, gatos e pequenos ruminantes em áreas endêmicas em diferentes estados brasileiros. Acta Scie. Vet., v. 47, p.1-10, 2019. doi: 10.22456/1679-9216.91878

MÓSENA et al. Detection of enteric agents into a cats' shelter with cases of chronic diarrhea in Southern Brazil. Pesq. Vet. Bras., v.39, n.8, p.630-634, 2019. doi: 10.1590/1678-5150-pvb5987

MUNDIM, T.C.D. et al. Frequência de helmintos em gatos de Uberlândia, Minas Gerais. Arq. Bras. Med. Vet. Zootec., v.56, n.4, p.562,563 2004. doi: 10.1590/S0102-09352004000400022

NARASIMHAM, M.V. et al. Dipylidium caninum infection in a child: a rare case report. Indian J. Med. Microbiol., v.31, n.1, p.82-84, 2013. doi: 10.4103/0255-0857.108738

PIVOTO, F.L. et al. Ocorrência de parasitos gastrointestinais e fatores de risco de parasitismo em gatos domésticos urbanos de Santa Maria, RS, Brasil. Ciênc. Rural, v.43, n.8, p.1453-1458, 2013. doi: 10.1590/S0103-84782013000800018
RAGOZO, A.M.A. et al. Ocorrência de parasitos gastrintestinais em fezes de gatos das cidades de São Paulo e Guarulhos. Braz. J. Vet. Res. Animal Scie., v.39, n.5, p.244-246, 2002. doi: 10.1590/ S1413-95962002000500005

RAMOS, D.G.S. et al. Survey of helminth parasites of cats from the metropolitan area of Cuiabá, Mato Grosso, Brazil. Rev. Bras. Parasitol. Vet., v.22, n.2, p.201-206, 2013. doi: 10.1590/S198429612013000200040

RAMOS et al. Endoparasites of household and shelter cats in the city of Rio de Janeiro, Brazil. Braz. J. Vet. Parasitol., v.29, n.1, e012819, 2020. doi: 10.1590/s1984-29612019110

RASSOULI, M. et al. Aelurostrongylus abstrusus in a stray cat's blood stream. Comparative Clin. Pathol., v.14, n.4, p.773-775, 2015. doi: 10.1007/s00580-014-1979-6

RENDTORFF, R.C. The experimental transmission of human intestinal protozoan parasites. II. Giardia lamblia cysts given in capsules. Am. J. Hyg., v.59, n.2, p.209-220, 1954. doi: 10.1093/ oxfordjournals.aje.a119634

ROCHA, M.J.; WEBER, D.M.; COSTA, J.P. Prevalência de larvas migrans em solos de parques públicos da cidade de Redenção, estado do Pará, Brasil. Ver. Pan-Amazônica Saúde, v. 10, p.1-8, 2019. doi: 10.5123/S2176-6223201901607

SALOMÃO, M. et al. Ultrasonography in hepatobiliary evaluation of domestic cats (Felis catus, L., 1758) infected by Platynosomum looss, 1907. Int. J. Appl. Res. Vet. Med., v.3, n.3, p.271-279, 2005.

SANTARÉM, V.A.; GIUFFRIDA, R.; ZANIN, G.A. Larva migrans cutânea: ocorrência de casos humanos e identificação de larvas de Ancylostoma spp em parque público do município de Taciba, São Paulo. Rev. Soc. Bras. Med. Trop., v.37, n.2, p.179181, 2004. doi: 10.1590/S0037-86822004000200014

SERRA, C.M.B.; UCHÔA, C.M.A.; COIMBRA, R.A. Exame parasitológico de fezes de gatos (Felis catus domesticus) domiciliados e errantes da região metropolitana do Rio de Janeiro, Brasil. Rev. Soc. Bras. Med. Trop., v.36, n.3, p.331-334, 2003. doi: 10.1590/S0037-86822003000300003

SILVA, H.C. et al. Fauna helmíntica de cães e gatos provenientes de alguns municípios do Estado de São Paulo. Semina Ciênc. Agrárias, v.22, n.1, p.67-71, 2001.

TAPARÓ, C.V. et al. Comparação entre técnicas coproparasitológicas no diagnóstico de ovos de helmintos e oocistos de protozoários em cães. Rev. Bras. Parasitol. Vet., v.15, p.1-5, 2006.

TAYLOR L.H.; LATHAM, S.M.; WOOLHOUSE, M.E.J. Risk factors for human disease emergence. Philos. Transactions Royal Soc., v.356, p.983-989, 2001. doi: 10.1098/rstb.2001.0888

TORRICO, K.J. et al. Ocorrência de parasitas gastrintestinais em cães e gatos na rotina do laboratório de enfermidades parasitárias da FMVZ/UNESP-BOTUCATU, SP. Rev. Bras. Parasitol. Vet., v.17, n.1, p.182-183, 2008.

TRAVERSA, D.; GUGLIELMINI, C. Feline aelurostrongylosis and canine angiostrongylosis: a challenging diagnosis for two emerging verminous pneumonia infections. Vet. Parasitol., v.157, n.3-4, p.163-174, 2008. doi: 10.1016/j.vetpar.2008.07.020

WHO - World Health Organization. Zoonoses and veterinary public health. The control of neglected zoonotic diseases. 2009. Available in: http://www. who.int/zoonoses/control_neglected_ zoonoses/ en/index.html Accessed on: 14 may 2020. 